\title{
Self Regulated Learning dan Self Efficacy Mahasiswa Tim Debat Bahasa Arab al-Kindy
}

\author{
Nuril Mufidah \\ Universitas Islam Negeri Maulana Malik Ibrahim Malang \\ nurilmufidah86@uin-malang.ac.id \\ Warisma Riski Nuryani \\ warismariski98@gmail.com \\ Universitas Islam Negeri Maulana Malik Ibrahim Malang
}

\begin{abstract}
The skill of speaking Arabic is a demand in the campus world and after graduation as a form of readiness to enter the workforce in the global era. Teaching kalam with the debate method for students besides being able to improve ability also adds courage as a form of self-efficacy. Students with Self-regulated learning can complete lecture obligations properly and can participate in extra debate activities as a means of self-development. This study aims to determine whether there is an influence of self-regulated learning and self-efficacy for adult students in Arabic learning especially debate program. The subject of this study are 7 students who had participated in the National or International Arabic debate competition. The study used a descriptive qualitative research type of case study-retrieval of data through interviews and documentation. The results of this study indicate that $78 \%$ of their success is influenced by the existence of self-regulated learning and self-efficacy in the debate. The strategy of learning debate by using native speaker videos that are studied independently by each member. Then each member displays the results of their training day in front of the senior.
\end{abstract}

Keywords: Self-regulated learning, Self-efficacy, speaking skill

\begin{abstract}
Abstrak
Keterampilan berbahasa Arab merupakan tuntutan di dunia kampus dan setelah lulus sebagai bentuk kesiapan untuk memasuki dunia kerja di era global. Pengajaran kalam dengan metode debat bagi siswa selain mampu meningkatkan kemampuan juga menambah keberanian sebagai bentuk self-efficacy. Siswa dengan pembelajaran mandiri dapat menyelesaikan kewajiban kuliah dengan benar dan
\end{abstract}


dapat berpartisipasi dalam kegiatan debat ekstra sebagai sarana pengembangan diri. Penelitian ini bertujuan untuk mengetahui apakah ada pengaruh self-regulated learning dan self-efficacy untuk siswa dewasa dalam pembelajaran bahasa Arab khususnya program debat. Subjek penelitian ini adalah 7 siswa yang telah berpartisipasi dalam kompetisi debat Arab Nasional atau Internasional. Penelitian ini menggunakan jenis penelitian kualitatif deskriptif studi kasuspengambilan data melalui wawancara dan dokumentasi. Hasil penelitian ini menunjukkan bahwa 78\% dari keberhasilan mereka dipengaruhi oleh keberadaan belajar mandiri dan self-efficacy dalam perdebatan. Strategi belajar debat dengan menggunakan video penutur asli yang dipelajari secara independen oleh masing-masing anggota. Kemudian setiap anggota menampilkan hasil hari pelatihan mereka di depan senior.

Kata kunci: Belajar mandiri, Selfefficacy, keterampilan berbicara

\section{Pendahuluan}

Tujuan utama dalam pendidikan adalah untuk meningkatkan mutu kwalitas sumber daya manusia (SDM). Pendidikan membantu menyiapkan mutu Peserta didik yang berilmu, berteknologi, berketerampilan tinggi dan tentunya berkarakter baik secara moral, dan agama. ${ }^{1}$ Pada tingkatan perguruan tinggi media pembelajaran, metode pembelajaran, atau teknik-teknik pembelajaran hanya berpengaruh kecil dalam peningkatan kwalitas mahasiswa. Pembelajaran yang lebih efektif dalam tingkat dewasa adalah dengan cara diskusi, studi kasus, metode insiden kritis, simulasi, demonstrasi, atau sejenisnya. ${ }^{2}$

Mahasiswa dianggap cukup dewasa dan mampu mencari apa yang mereka butuhkan secara mandiri. Sesuai pemikiran orang dewasa yang mencari kemampuan dan pengalaman secara mandiri dalam menentukan pilihan. Adapun pendidikan yang ditempuh dalah perguruan tinggi adalah usaha untuk memecahkan permasalahan. ${ }^{3}$

Namun, tidak semua mahasiswa menyadari apa yang menjadi kebutuhan mereka. Walaupun, metode, strategi, atau media yang digunakan sangat menarik bagi ukuran mahasiswa. Pada faktanya mahasiswa masih kurang dapat menentukantujuan belajar. ${ }^{4} \mathrm{Hal}$ ini berpengaruh terhadap pemilihan strategi maupun metode belajarnya. Dalam setiap siklus kegiatan belajar mengajar

${ }^{1} \mathrm{H}$. Abd. Wahid Tahir, 'Pengembangan Manajemen Sumber Daya Manusia Terbadap Peningkatan Peningkatan Mutu Pendidikan', Jurnal Inspirasi Pendidikan, 1 (2017) hlm 1.

${ }^{2}$ Yusnimar Yusri, 'Strategi Pembelajaran Andragogi', Al-Fikra, 12 No. 1 (2013), hlm. 30.

${ }^{3}$ Sunhaji, 'Konsep Pendidikan Orang Dewasa', Jurnal Kependidikan, 1 (2013), hlm.4.

${ }^{4}$ Eva Latipah, 'Pengaruh Strategi Experiential Learning Terhadap Self Regulated Learning Mahasiswa', Humanitas, 14 No.1 (2017), hlm.43. 
biasanya melaui proses merencanakan, menyiapkan, dan mengontrol emosi mereka sendiri. Kuranganya kemampuan mengorganisasi dan mengontrol diri sebagai efek dari self regulated learning menyebabkan kesulitan bagi mahasiswa dalam belajar. Dampaknya akan muncul gejala negatif, seperti lebih suka mencontek tugas teman, mengundur-undur tugas, lebih banyak bermain dari pada belajar, dan kurang percaya akan kemampuan diri sendiri.

Mahasiswa yang meiliki self regulated learning dengan baik akan mampu menjalani dan menyelasaikan tugas perkuliahan dengan baik. Begitu tugas wajib sebagai penentu kelulusan sudah diselesaikan maka mahasiswa memiliki kesempatan mengembangkan diri dan potensinya dalam intra maupun ekstra kampus. Pihak universitas menyediakan banyak pilihan organisasai di intra kampus seperti Senat Mahasiswa (SEMA), Dewan Eksekutif Mahasiswa (DEMA), dan Himpunan Mahasiswa Jurusan (HMJ).

HMJ Pendidikan Bahasa Arab mempunyai dua Badan Semi Otonom (BSO) untuk mengembangkan potensi dan minat mahasiswa. BSO El-Fatih mengembangkan keterampilan mahasiswa dibidang penerbitan seperti majalah dinding dan buletin. BSO Al-Kindy mengembangkan keterampilan mahasiswa dalam beberapa aspek kebahasaan; seperti debat bahasa arab, kbitobah, insya', syi'ir, dan membaca berita (qiro'atul akbbar).

Al-Kindy mengirimkan delegasi secara berkala dalam berbagai perlombaan kebahasaan baik tingkat regional, nasional dan internasional. Secara umum Al-Kindy merupakan "wajah" Pendidikan Bahasa Arab UIN Maulana Malik Ibrahim Malang pada dunia kompetisi. Oleh karena itu menarik untuk diteliti kemampuan self regulated learning dan self efficacy mahasiswa yang tergabung dalam organisasi ini. Selain prestasi diluar kampus, terbukti mereka juga mampu menyelesaikan perkuliahan dengan nilai memuaskan.

Penelitian yang telah dilakukan sebelumnya dilakukan Maisaroh ${ }^{5}$ untuk menggambarkan pengaruh self efficacy dan self regulated learning berpengaruh terhadap stimultan terhadap prestasi mahasiswa Ekonomi. Bekti Dwi dan Hermien $^{6}$ terdapat keterkaitan antara self regulated learning dan self efficacy dengan prestasi akademik siswa dengan pengaruh presentase 73,2\%. Amarullah $\mathrm{S}^{7}$ pengaruh self efficacy dan self regulated learning dalam prokrastinasi akademik mahasiswa. Dibuktikan dengan adanya persentase $25 \%$ pengaruh self regulated learning kepada prokrastinasi akademik mahasiswa.

${ }^{5}$ Maisaroh, 'Pengarub Self Efficacy Dan Self Regulated Learning Terbadap Prestasi Belajar Pada Mahasiswa Fakultas Ekonomi Universitas Negeri Jakarta', JP Journal \& Proceeding, 5.No. 1 (2015).

${ }^{6}$ Bekti D. R. dan Hermien Laksmiwati, 'Hubungan Antara Self Efficacy Dan Self Regulated Learning Dengan Prestasi Akademik Matematika Siswa SMAN 2 Bangkalan', Character, 03.2 (2014), hlm.1.

${ }^{7}$ Amarullah Sidkin, 'Pengarub Self Efficacy Dan Self Regulated Learning Terbadap Prokrastinasi Akademik Pada Mahasiswa’ (Universitas Islam Negeri Syarif Hidayatullah, 2016). 
Adapun penelitian iniberfokus pada hubungan self regulated learning dan self efficacy mahasiswa tim debat bahasa arab Al-Kindy. Penelitian ini bertujuan untuk mendeskripsikan dan menganalisis self regulated learning dan self efficacy mahasiswa serta staretegi belajar keterampilan berbicara (mabarah kalam) khususnya debat (munadharah al-ilmiyah). Hasil penelitian ini bermanfaat untuk memberikan alternatif baru untuk strategi belajar bahasa Arab tingkat mahasiswa khususnya keterampilan berbicara.

\section{Hasil dan Pembahasan}

\section{A. Self Regulated Learning}

Zimmerman (di dalam Siti Minarti dan Siti Fatimah) mengartikan self regulated learning adalah kemampuan belajar untuk berparan aktif dalam proses belajar, baik secara meta-kognitif, motivasional dan behavioral. Secara metakognitif maka pelajar yang mengatur diri merencanakan, mengorganisasi, menginstruksi diri, memonitor dan mengevaluasi dirinya dalam proses belajar. Secara motivasional maka pelajar yang belajar merasa bahwa dirinya kompeten, memiliki keyakinan diri (self efficacy) dan memiliki kemandirian. Sedangkan secara behavioral, pelajar yang belajar menyeleksi, menyusun, dan menata lingkungan agar lebih optimal dalam belajar. ${ }^{8}$

Menurut Bandura di dalam Ni'matur Rizqiyah mengartikan self regulated learning adalah kemampuan untuk mengontrol perilaku diri, dan hal ini merupakan salah satu dari sekian penggerak utama kepribadian manusia. ${ }^{9}$ Adanya strategi self regulated learning mahasiswa adanya anggapan:

Pertama, pelajar lebih dituntut berperan aktif dan konstruktif saat proses belajar. Jadi, mahasiswa tidak hanya saja duduk pasif mendengarkan penjelasan dari dosen saja, melainkan mereka mendengarkan penjelasan dosen dan mereka mampu membangun pemahaman mereka sendiri melalui penjelasan.

Kedua, pelajar mampu mengontrol dirinya dari aspek kognisi, motivasi, perilaku dan lingkungan. Bukan dalam artian dalam satu waktu mahasiswa harus mampu mengontrol semua aspek. Karena tidak dipungkiri adanya kendala dari segi ekonomi, biologis, atau lingkungan yang mejadi hambatan bagi mahasiswa dalam kontroling diri sendiri. ${ }^{10}$

Ketiga, pelajar mampu menetapkan tujuan individu. Jadi, setiap mahasiswa mampu menetapkan atas standar atau tujuan yang hendak mereka

${ }^{8}$ Siti Suminarti dan Siti Fatimah, 'Self Regulated Learning (SRL) Dalam Meningkatkan Prestasi Akademik Pada Mahasiswa', Jurnal Ilmiah Psikologi Terapan, 01 No. 1 (2013) hal 147.

${ }^{9}$ Ni'matur Rizqiyah, 'Pengaruh Strategi Regulasi Diri Dalam Belajar Dan Dukungan Sosial Orang Tua Terbadap Prestasi Belajar Siswa-Siswi SMP Hasanuddin Sepanjang Gondanglegi? (UIN Maulana Malik Ibrahim Malang, 2016) hal 22.

${ }^{10}$ Paul R. Pintrich, The Role Of Goal Orientation In Self-Regulated Learning Handbook of SelfRegulation (San Diego: Academic Press, 2000) hal 452. 
capai. Tugas dosen hanya memantau perkembangan. Dengan menyesuaikan kognisi, motivasi, dan perilaku mahasiswa. ${ }^{11}$

Keempat, pengaturan diri dari kognisi, motivasi, dan perilaku yang sebagai perantara hubungan antara orang, keadaan, dan pencapaian akhirnya. Sebagian besar asumsi beranggapan bahwa pengaturan diri terkait dengan hasil. Walaupun banyak penelitian yang menguji pengaturan diri sebagai hasil. ${ }^{12}$

Dari anggapan-anggapan tersebut Paul R. Pintrich di dalam Abd. Mukhid mendefinisikan self-regulated learning suatu proses yang aktif, konstruktif, pelajar dituntut mampumenetapkan tujuan belajar mereka dan kemudian memonitor, mengatur, dan mengontrol kognisi, motivasi, dan perilaku mereka, yang dipandu oleh tujuan-tujuan mereka dan segi kontekstual terhadap lingkungan. ${ }^{13}$

Dari penjelasan tersebut dapat disimpulkan bahwa strategi self-regulated learning adalah kemampuan pelajar belajar mandiri secara aktif dan kontruktif dan menetapkan rancangan, instruksi diri, monitor, motivasi, dan evaluasi untuk dirinya dalam belajar.

Mahasiswa masuk dalam kategori mampu untuk melakukan belajar mandiri ketika mahasiswa sudah mampu melalui tiga tahapan. Tahapan pertama perencanaan (forethought phase), tahapan kedua penampilan atau mengontrol kemampuan (performance or valitional control plase) dan tahapan ketiga meregulasi atau fefleksi (regulated learning or self-reflectiion phase). ${ }^{14}$

Tahapan pertama perencanaan (forethought phase) pada tahapan ini mahasiswa mampu merancang, merencanakan, dan mencari informasi terkait dengan tujuan yang akan dicapai. Berkaitan dengan mahasiswa mereka harus mampu setiap mahasiswa merencanakan, merancang dan mencari informasi dari jauh-jauh hari. Dengan tujuan adanya persiapan yang matang dapat membuat pencapaian tujuan dapat secara mudah.

Tahapan kedua performansi atau mengontrol kemampuan (performance or validional control phase) pada tahapan ini mahasiswa ada tiga langkah untuk mengontrol perilaku ${ }^{15}$. Langkah pertama observasi diri (self-observation) sebelumnya kita melihat kemampuan diri untuk mempersiapkan untuk mencapai tujuan. Langkah kedua keputusan (judgment) adanya perbandingan untuk mengukur kemampuan dengan suatu standar yang dibutuhkan dalam mencapai

${ }^{11}$ Paul R. Pintrich, hlm.452.

${ }^{12}$ Paul R. Pintrich, hlm.455.

${ }^{13} \mathrm{Abd}$. Mukhid, 'Strategi Self-Regulated Learning (Perspektif Teoritik)', Tadris, 3 Nomor 3 (2008), hlm.225.

${ }^{14}$ Eva Latipah, Pengaruh Strategi Experiential Learning Terbadap Self Regulated Learning Mahasiswa', Humanitas, 14 No.1 (2017), hlm.45.

${ }^{15} \mathrm{Abd}$. Mukhid, hlm.224. 
tujuan. Langkah ketiga respon diri (self-response) adanya tindak lanjut mengenai kemapuan yang dimiliki.

Tahapan ketiga adalah meregulasi atau refleksi (regulated learning or selfreflection phase) dari tahapan ini semua rangkaian kegiatan yang telah dilakukan diadakannya evaluasi. Selain mengevaluasi kinerja, diadakan pula evaluasi diri (self evaluation) apa yang seharusnya dilakukan oleh dirinya. Ketika hasil perbandingan menyatakan kemampuan lebih baik maka perlu adanya reward kepada diri sendiri. Sebaliknya ketika hasil perbandingan lebih rendah maka perlu adanya punishment dalam bentuk penambahan jam belajar atau lainnya yang berdampak baik. Tindakan apa yang harus diambil untuk refleksi untuk perencanaan dan dirinya untuk mencapai tujuan. ${ }^{16}$

Selain adanya tindakan strategi lainnya seperti self regulated learning yaitu evaluasi diri (self evaluation), pengorganisasian (organising) dan transformasi (transforming), menetapkan tujuan dan perencanaan (goal setting and planning), dan mencari informasi (seeking information), membuat dan memeriksa catatan (keeping records and monitoring), mengatur lingkungan (environment structuring), mencari bantuan (seeking social assistance), konsekuensi diri (self concequences), mengulang dan mengingat (rehearsing and memorizing), mencari bantuan kepada teman sebaya, guru, atau orang dewasa (seeking social assistance) dan melihat ulang catatan (review records). ${ }^{17}$

\section{B. Self Efficacy}

Self efficacy adalah keyakinan seseorang atas kemampuan dirinya untuk merancang dan melalakukan kegiatan untuk mencapai tujuan tertentu. ${ }^{18}$ Self efficacy atau keyakinan menjadi faktor utama dalam kesuksesan seseorang dalam pencapaian tujuan. ${ }^{19}$ Dengan adanya kayakinan pada diri sendiri menjadi pendorong bagi mahasiswa untuk terus melakukan kegiatan yang membantunya dalam mencapai tujuan.

Sedangkan menurut Touillet self efficacy adalah pertimbangan diri yang mempengaruhi pertimbangan dirinya untuk memperlakukan kondisi lingkungan eksternal. ${ }^{20}$ Dapat diambil kesimpulan dari pengertian tersebut dengan adanya self efficacy dapat membantu mahasiswa beradaptasi dengan lingkungan. Dan dapat membantu mereka untuk berkembang lebih baik pada lingkungan baru.

\footnotetext{
${ }^{16}$ Latipah, hlm.45 .

${ }^{17}$ Putri Saraswati, 'Strategi Self Regulated Learning Dan Prokrastinasi Akademik. Tertadap Prestasi Akademik', Jurnal Intuisi, 9 (3) (2017), hlm.215.

${ }^{18}$ Abd.Mukhid, 'Self Efficacy (Perspektif Teori Kognitif Sosial Dan Implikasinya Terbadap Pendidikan)', Tadris, 4 Nomor 1 (2009), hlm.107.

${ }^{19}$ Abd.Mukhid, hlm.108.

${ }^{20}$ M. Irfan dan Veronika Suprapti, 'Hubungan Self-Efficacy Dengan Penyesuaian Diri Terhadap Perguruan Tinggi Pada Mahasiswa Baru Fakultas Psikologi Universitas Airlangga', Jurnal Psikologi Pendidikan Dan Perkembangan, 3 (2013), hlm.174.
} 
Keyakinan self efficacy akan mempengaruhi individu mahasiswa untuk melakukan sesuatu yang diperlukan untuk mencapai tujuan. Dengan kekuatan keyakinan tersebut akan menentukan tidak atau dilakukannya sebuah tindakan, seberapa usaha yang akan dihasilkan, dan seberapa lama usaha untuk menghadapi tantangan. ${ }^{21}$ Keyakinan ini tidak ada kaitan dengan keterampilan mahasiswa melainkan berkaitan dengan keputusan yang mereka putuskan untuk mengembangkan sebuah keterampilan. ${ }^{22}$

Kadar self efficacy atau keyakinan pada diri sendiri dari dalam diri mahasiswa pun berbeda-beda. Seberapa besar keyakinan yang dimiliki mahasiswa dalam dirinya dapat diketahui dari seberapa banyak masalah-masalah yang telah mereka hadapi. ${ }^{23}$ Semakin banyak mereka beradaptasi semakin luaspula pengalaman mereka.

Keyakinan yang dimaksud dalam self efficacy adalah keyakinan akan dirinya dalam hal potensi. ${ }^{24}$ Cara pandang orang yang memiliki keyakinan kuat dengan orang yang rendah diri juga mempengaruhi mereka mencapai tujuan. Dimana mahasiswa yang penuh keyakinan yang kuat akan memandang sebuah permasalahan sebagai tantangan yang harus dilalui. Sebaliknya dengan mahasiswa yang sangat kurang keyakinan akan dirinya melihat tugas-tugas yang berat sebagai ancaman bagi kesuksesan mereka.

Permasalahan rendahnya self efficacy pada mahasiswa akan mempengaruhi pola pikir mereka dalam proses pembelajaran. ${ }^{25}$ Contohnya ketika mahasiswa memiliki keyakinan rendah akan kemampuan dirinya maka mahasiswa akan lebih takut mencoba melakukan kegiatan baru, takut mencoba berbicara di depan orang banyak, dan identik tergantung pada orang lain dalam belajar.

\section{Pengajaran Maharah Kalam}

Penerapan bahasa asing tidak semudah menerapkan bahasa ibu yang setiap hari digunakan untuk berkomunikasi dan selalu didengarkan setiap hari sebaliknya dengan bahsa asing khususnya bahasa arab. Menurut Nuha di dalam Aminah beranggapan bahwa strategi atau metode yang mudah dalam pembelajaran bahasa arab sangat diperlukan pada proses pembelajaran. ${ }^{26}$

${ }^{21}$ Abd. Mukhid, hlm.115.

${ }^{22}$ Abd. Mukhid, hlm.114.

${ }^{23}$ Rohmad Efendi, 'Self Efficay: Studi Indigenous Pada Guru Bersuku Jawa', Journal of Social and Industrial Psichology, 2 (2013), hlm.62.

${ }^{24}$ Abd.Mukhid, hlm.116.

${ }^{25}$ Maisaroh, 'Pengaruh Self Efficacy Dan Self Regulated Learning Terhadap Prestasi Belajar Pada Mahasiswa Fakultas Ekonomi Universitas Negeri Jakarta', JP Journal \& Proceeding, 5.No. 1 (2015), hlm.2.

${ }^{26}$ Aminah dkk, 'Pengembangan Metode Pembelajaran Keterampilan Berbicara Bahasa Arab Dengan Kooperatif Berbasis Teori Kecerdasan Majemuk Pada Siswa Kelas VII Madrasah Tsanawiyah', Journal Of Arabic Learning and Teaching, 7.1 (2018), hlm.9. 
Pembelajaran bahasa arab sangat dibutuhkan bagi mahasiswa terutama dalam bidang pengetahuan. Bermanfaat sebagai bahasa komunikatif maupun sebagai bahasa pemahaman ilmu pengetahuan. ${ }^{27}$ Keterampilan dalam berbicara merupakan salah satu fokus keterampilan yang ingin dicapai dalam pembelajaran bahasa.

Maharah kalam adalah sebuah kemahiran dalam pengungkapan dan penyebaran sebuah pernyataan atau informasi yang disampaikan secara lisan. ${ }^{28}$ Lebih fokuskan pada pembenaran pada pelafalan bunyi, ketepatan ketentuan susunan bahasa, dan pada pengungkapan ide gagasan secara lisan.

Menurut Vallet dalam Nurmasyithah menuliskan bahwa maharah kalam dalam pembelajaran bahasa arab adalah salah satu pokok pembelajaran yang harus dikuasai oleh pelajar bahasa arab. ${ }^{29}$ Ketika pelajar sudah mampu berbacara dengan baik dengan bahasa asing maka tujuan pembelajaran bahasa arab bisa tercapai.

Pengertian lainnya menjelaskan maharah kalam adalah keterampilan berbicara. Keterampilan berbicara dalam mengungkapan bahasa sesuai dengan ide dan gagasan yang dipikirkan..$^{30}$ Berkaitan dengan tujuan pembelajaran bahasa Arab menjadikan bahasa Arab sebagai bahasa komunikasi. ${ }^{31}$ Dari pengertian di atas dapat diambil garis besar, maharah kalam adalah keterampilan dalam berbicara dalam bidang bahasa Arab dan mengungkapkan gagasan pemikiran dengan ketentuan dan susunan yang benar.

Tujuan dari pembelajaran maharah kalam pada mahasiswa adalah dapat berbicara dengan tepat dan dapat mempertangungjawabkan perkataannya. ${ }^{32}$ Dengan tujuan yang ada setiap mahasiswa berhak mendapatkan pembelajaran yang mengasah dalam keterampilan berbicara. Selain itu dengan maharah kalam setiap mahasiswa dapat belajar menggunakan bahasa yang tepat dan dapat dipertanggungjawabkan psetiap perkataannya.

Kesulitan yang akan dihadapi dalam pembelajaran mabarah kalam diantaranya: 1). Kesulitan dalam artikulasi, 2). Gagap pada saat mengucapan

${ }^{27}$ Bulkisah, 'Pembelajaran Bahasa Arab Pada Pengguruan Tinggi Agama Islam Di Indonesia', Jurnal Ilmiah DIDAKTIKA, 12.2 (2012), hlm.311-313.

${ }^{28}$ Rahmaini, 'Strategi Pembelajaran Maharah Kalam Bagi Non Arab', Jurnal Ihya'ul Lughoh, 2 (2015), hlm.225.

${ }^{29}$ Nurmasyithah Syamaun, 'Pembelajaran Maharah AL-Kalam Untuk Meningkatkan Keterampilan Berbicara Mahasiswa Program Studi Pendidikan Bahasa Arab Fakultas Tarbiyah Dan Keguruan UIN Ar-Raniry Banda Aceh', Jurnal Lisanuna, 4.No. 2 (2015), hlm.334.

${ }^{30}$ Nurmasyithah Syamaun, 'Pembelajaran Mabarah al-Kalam Untuk Meningkatkan Keterampilan Berbicara Mahasiswa Program Studi Pendidikan Bahasa Arab Fakultas Tarbiyah Dan Keguruan UIN Ar-Raniry Banda Aceh', Jurnal Lisanuna, 4.No. 2 (2015), hlm.347.

${ }^{31}$ Syamaun, hlm.345.

${ }^{32}$ Muspika Hendri, 'Pembelajaran Keterampilan Berbicara Bahasa Arab Melalui Pendekatan Komunikatif, Jurnal Kependidikan Islam, 3.2 (2017), hlm.201-202. 
kosakata, 3). Pengacauan dalam pelafalan kata karena terlalu cepat, 4). Kesulitan dalam mendengar bunyi arab. ${ }^{33}$ Dari kesulitan yang ada, pembelajaran memerlukan strategi pembelajaran yang baik dan tepat dalampembelajaran bahasa arab.

Strategi pembelajaran maharah kalam juga bervariatif. Lalu pembelajaran yang seperti apa yang baik dan sesuai dengan pembelajaran maharah kalam. Secara umum model pembelajaran maharah kalam diantaranya ${ }^{34}: 1$ ). Tanya jawab, atau pembelajaran kooperatif yang lebih identik dalam pembelajaran bahasa Arab sebagai bahasa komunikatif. 2). Menghafalkan dialog, bertujuan agar setiap individu mampu mengasah keterampilan berbicara dengan cara menghafal dan dapat mendemonstrasikan dari setiap percakapan. 3). Percakapan terpimpin atau debat, percakapaan antara dua kelompok yang saling beradu argumen bertujuan dapat mengembangkan imajinasi setiap individu. 4). Percakapan bebas, setiap individu dapat berbicara bebas mengenai sebuah tema dengan tetap adanya pengawasan dari pelatih.

Metode, teknik, atau strategi yang akan diterapkan dalam pembelajaran maka harus disesuaikan dengan kemampuan dari setiap peserta didik mubtadi, muttawashit, atau mutaqoddim. Kesulitan ini yang sering terjadi pada pengajar ataupun pelajar bahasa Arab, sehingga menimbulkan ketidak efektifan dalam proses belajar ${ }^{35}$. Dengan begitu, penyesuaian pembelajaran dengan kemampuan sangat diperlukan untuk menciptakanbelajar bahasa Arab yang baik dan tepat dalam pembelajaran.

Penelitian ini menggunakan metode penelitian deskriptif kualitatif jenis studi kasus. Tujuan dari penelitian ini mendeskripsikan dan menganalisis strategi self regulated learning pada mahasiswa dalam kemampuan berbicara bahasa arab terutama pada debat.

Subjek penelitiannya adalah mahasiswa Al-Kindy pendidikan bahasa arab 2017 UIN Maulana Malik Ibrahim Malang, 7 Anggota yang aktif mengikuti perlombaan debat.

Teknik pengumpulan data dalam penelitian ini melalui observasi, wawancara, dan dokumentasi dalam terhadap proses belajar. Selain memperoleh data deskriptif tentang proses berlatih debat, untuk mengetahui proses belajar debat anggota Al-Kindy juga menggunakan dokumentasi video. Pengambilan dokumentasi untuk mengetahui bukti-bukti nyata atas prestasi yang telah diraih

\footnotetext{
${ }^{33}$ Rahmaini, hlm.231.

${ }^{34}$ Kuswono, 'Konsep Dasar Pembelajaran MAharah Al-Kalam', An-Nuha, 4.1 (2017), hlm.5-6.

${ }^{35}$ Devita Mawarni, 'Penerapan Pembelajaran Maharah Kalam Dengan Metode Langsung; Studi Kasus Di SMA IT Abu Bakar Yogyakarta' (Universitas Islam Negeri Sunan Kalijaga Yogyakarta, 2016), hlm.2-3.
} 
oleh anggota Al-Kindy. Dilengkapi dengan data wawancara untuk mengklarifikasi data lebih lanjut.

\section{Self Regulated Learning dan Self Efficacy Pada Mahasiswa Al-Kindy}

Pengambilan sempel dari 7 angkatan 2016 mahasiswa Al-Kindy Pendidikan Bahasa Arab UIN Maulana Malik Ibrahim Malang yang pernah mengikuti lomba debat bahasa arab. Pengaruh strategi self regulated learning dan self efficacy pada mahasiswa Al-Kindy Pendidikan Bahasa Arab UIN Maulana Malik Ibrahim Malang mencapai persentase $70 \%$ anggota. Dari persentase tersebut sebagian besar mahasiswa Al-Kindy sudah mampu melakukan pengaturan pada belajar mandiri mereka. Dibuktikannya sebelum adanya latihan sebagian dari mereka sudah mempersiapkan diri untuk tampil baik di depan senior. Selain itu kebanyakan mereka sudah berani berbicara di depan temanteman dengan baik.

Kekurangannya 30\% anggota lainnya lemah, persentase tersebut menunjukkan sebagian kecil dari mahasiswa Al-Kindy belum mampu mengatur belajar mandiri dengan baik. Namun, secara teori penerapan belajar mandiri mereka sudah teratur walaupun masih ada bagian-bagian yang belum bisa dilaukan secara optimal. Dibuktikan dengan masih adanya anggota yang semangat mengikuti latihan secara rutin hanya karena akan mengikuti sebuah perlombaan. Saat latihan rutin harian mereka masih banyak anggota yang berhalangan hadir untuk mengikuti latihan.

Sedangkan pada latihan rutin yang dikhususkan bagi anggota yang akan berangkat dalam sebuah perlombaan juga masih yang masih belum bisa maksimal mengikuti latihan, diukur dari tidak adanya motivasi besar bagi mereka saat mengikuti sebuah perlombaan. Mulai dari persiapan diri dalam mengikuti sebuah latihan sendiri masih belum ada. Oleh karena itu, timbul banyak kesulitan yang dihadapi mereka pada saat pembelajaran. Seperti kurangnya waktu untuk persiapan untuk setiap latihannya, fokus yang terbagi dengan tugas kuliah lainnya, masih belum bisa menegontrol diri dalam pembagian waktu dan lainnya.

Dalam hal self efficacy, adalah nilai tambahan bagi mahasiswa Al-Kindy Pendidikan Bahasa Arab UIN Maulana Malik Ibrahim Malang. Potensi dalam keterampilan berbicara bahasa arab sendiri bagi mahasiswa Al-Kindy sudah dalam kategori tingkatan tinggi. Dengan adanya latihan hanya sebagai tambahan kegiatan bahasa yang bersifat mengembangkan. Yang dibuktikannya adanya kemenangan dari setiap event perlombaan debat bahasa arab. Dibuktikan juara 1 pada perlombaan Zukhruf di UIN Sunan Ampel Surabaya tingkat Nasional, juara 2 pada perlombaan Fesrival Jazirah Arab (FJA) Bahasa dan Sastra Arab UIN Malang dan juara 3 pada perlombaan Pekan Arobi di Universitas Negeri Malang dan lain-lainnya. 


\section{E. Staretegi Belajar Keterampilan Berbicara (maharah kalam) Khususnya Debat Al-Kindy}

Sebelum diadaannya latihan rutin, mahasiwa sudah mepersiapkan tema (mosi) yang akan ditampikan. Mulai pencarian materi mengenai permasalahan dan mendiskusikan mengenai tema bersama kelompok. Setiap anggota mendapatkan tugas masing-masing, dan mempersiapkan materi yang akan disampaikan sesuai porsi yang telah ditentukan.

Kegiatan latihan rutin mahasiswa Al-Kindy PBA UIN Maulana Malik Ibrahim Malang dilakukan dua cara. Pertama, latihan rutin semua anggota AlKindy dilaksanakan setiap hari jumat pukul 16.00- 17.00 WIB dan hari sabtu pukul 07.00-09.00 WIB. Selain anggota Al-Kindy sendiri kegiatan latihan rutin tersebut dihadiri oleh senior-senior dari anggota Al-Kindy untuk memberi penilaian dan masukan mengenai penampilan setiap anggotanya.

Kedua, latihan rutin bagi anggota yang mengikuti perlombaan diadakan setiap hari di waktu sore hari minimal dalam jangka waktu 7 hari sebelum hari perlombaan. Sebelumnya setiap anggota akan dibagi menjadi beberapa kelompok sesuai jumlah kelompok yang akan mengikuti perlombaan. Cara latihannya berbeda dengan latihan rutin mingguan, dengan cara setiap kelompok mendiskusikan mosi debat dan membagi tugas setiap mutakalim agar penyampaian lebih sistematis.

\section{F. Self Regulated Learning dan Self Efficacy Pada Mahasiswa}

Penentuan strategi dalam proses belajar juga diperlukan untuk menentukan proses belajar yang efektif bagi mahasiswa. Adanya penerapan strategi self regulaed learning dan self efficacy dalam proses belajar bahasa arab sangat membantu mahasiswa dalam perkembangan kemampuan secara mandiri. ${ }^{36}$ Dalam proses belajar bahasa Arab pada mahasiswa Al-Kindy juga menunjukkan dengan adanya penerapan strategi tersebut membuat mereka lebih mandiri dalam belajar dan mampu mengatasi permasalahan pribadi dalam belajar.

Setiap mahasiswa dikatakan mampu mengatur belajar mandiri ketika mereka mampu melakukan beberapa tahapan. Tahapan pertama perencanaan, setiap mahasiswa harus merancang setiap agenda yang akan mereka lakukan. ${ }^{37}$ Mulai tahap pencarian informasi, perencanaan setiap kegiatan, dan penentuan strategi belajar. Pengaturan belajar mandiri pada mahasiswa Al-Kindy dilakukan sebuah perencanan terlebih dahulu di awal kegiatan belajar. Setiap anggota akan mendata kegiatan perlombaan yang akan diadakan pada setahun kedepannya.

${ }^{36}$ Amrullah Sidkin, 'Pengarub Self Efficacy Dan Self Regulated Learning Terbadap Prokrastinasi Akademik Pada Mahasiswa’ (Universitas Islam Negeri Syarif Hidayatullah, 2016), hlm.20-25.

${ }^{37}$ Saraswati, hlm.214. 
Tahapan kedua, performansi dan pengontrolan $\operatorname{diri}^{38}$. Dalam tahapan ini dibagi menjadi tiga langkah. Langkah awal yaitu pengukuran awal atas kemampuan diri. Langkah kedua adanya keputusan untuk sebuah tindakan yang akan dilakukan. Langkah ketiga yaitu respon kemampuan diri. Dari ketiga langkah tersebut, penerapan pada mahasiswa Al-Kindy sudah mulai teratur mulai adanya penggolongan dari setiap kemampuan mahasiswa. Kemudian dari ketiga golongan sudah memiliki standar pencapaian dalam belajar. Dengan adanyanya pengoptimalan dalam belajar yang dilakukan disetiap hari jumat dan sabtu disetiap minggunya. Dari ketiga tahapan inidiharapkan mahasiswa mampu mengembangkan bakat mereka berbekalkan bakat yang sudah mereka miliki sebelumnya.

Tahapan ketiga, adalah refleksi. Refleksi diri penerapannya pada evaluasi diri. $^{39}$ Bentuk evaluasi dalam belajar dengan melihat sudahkan perencanaan di awal sudah sesuai dengan yang dilakukan. Selain itu untuk mengukur kemampuan, sudahkan adanya kemampuan dalam mahasiswa Al- Kindy sendiri. Evaluasi akan kemampuan diri dapat dilakukan oleh mahasiswa Al-Kindy dengan mengikuti sebuah perlombaan. Dengan begitu, mereka akan mengetahui seberapa jauh kemampuan mereka setelah adanya pelatihan rutin.

Tahapan-tahapan tersebut dilakukan untuk semakin mudah untuk mencapai tujuan yang telah dirancang. Setelah mengetahui hasil yang didapatkan maka akan adanya tindak lanjut yaitu pemberian sebuah reward atau punishment dari setiap hasil evaluasinya. Dalam hal ini setiap mahasiswa Al-kindy memilki cara yang berbeda-beda. Sebagian dari mereka memberikan reward atas apresiasi dari perkembangan, dan sebaliknya pemberian punishment bagi sebagian mahasiswa sebagai "gebrakan" baru mengembangkan prestasi untuk lebih berkembang kembali.

Bentuk reward yang mereka lakukan diantaranya seperti; meluangkan waktu sehari atau dua hari untuk merilekskan diri setelah beberapa minggu melakukan latihan, jajan-jalan ke tempat wisata yang terdapat pada kota diadakannya perlombaan, dan bermain game seharian penuh bagi penikmat game.

Sedangkan bentuk punishment yang sebagian dari mereka lakukan seperti; mengadakan tambahan latihan dengan menambah video debat bahasa Arab yang harus dipelajari, dan semakin rajin mengikuti latihan rutin.

Penerapan self efficacy pada sebuah proses belajar maka mahasiswa harus lebih siap, lebih kuat pertahan, dan emosional negatif lebih rendah dari pada emosional positif. ${ }^{40}$ Namun, dalam beberapa mahasiswa masih belum bisa

\footnotetext{
${ }^{38}$ Rizqiyah, hlm. 45.

${ }^{39}$ Latipah, hlm.45.

${ }^{40}$ Bekti D. R. dan Hermien Laksmiwati, 'Hubungan Antara Self Efficacy Dan Self Regulated Learning Dengan Prestasi Akademik Matematika Siswa SMAN 2 Bangkalan', Character, 03.2 (2014), hlm.5.
} 
mengontrol emosisonal negatif mereka seperti, malas mengikuti latihan, malu untuk mencoba dalam sebuah perlombaan, minder saat latihan, atau malas mencari materi untuk latihan dan lainnya.

Namun, bagi mahasiswa yang memiliki kemampuan self efficacy yang tinggi belum tentu mereka dapat menentukan metode yang efektif pada belajar mandiri. ${ }^{41}$ Karena self efficacy hanya sebagian kecil dari self regulated learning. Sebagian besar mahasiswa yang dapat mengatur belajar mandiri mereka memilki self efficacy yang tinggi. Tetap saja pengaruh dari self efficacy diperlukan dalam mengatur belajar mandiri. Dibuktikan semakin banyak kegagalan yang didapatkan mahasiswa mengajarkan mereka untuk terus berproses untuk mendapatkan cara belajar yang efektif bagi mereka. ${ }^{42}$

Begitu halnya dengan mahasiswa Al-Kindy, semakin banyak kekalahan yang mereka alami, maka semakin banyak perkembangan yang mereka dapatkan. Tergantung dengan tindakan apa yang mereka lakukan setelah adanya evaluasi. Cenderung mahasiswa yang memiliki self efficacy yang rendah setelah adanya hasil evalusi buruk mereka akan semakin memburuk. Dari penjelasan tersebut menyatakan akan adanya hubungan antara self regulated learning dan self efficay pada belajar mandiri. Kedua faktor mempengaruhi dalam pencapaian tujuan dalam proses belajar mandiri.

\section{G. Strategi Belajar Keterampilan Berbicara (Maharah Kalam) Khususnya Debat Al-Kindy}

Proses belajar untuk meningkatkan maharah kalam pada mahasiswa yang sudah memiliki kemampuan lebih maka model belajar dengan debat sangat sesuai untuk mengasah kemampuan maharah kalam. ${ }^{43}$ Proses belajar yang diterapkan dalm pembelajaran maharah kalam pada mahasiswa Al-Kindy menggunakan model debat dengan menentukan tema yang sudah ditentukan. Setiap minggunya mahasiswa Al-Kindy mengasah kemampuan maharah kalam untuk meningkatkan kemampuan mereka.

Cara debat yang diterapkan pada mahasiswa Al-Kindy diantaranya. Diawali penentuan tema yang diberitahukan satu hari sebelum hari latihan diadakan, dengan tujuan setiap mahasiswa mampu mempersiapkan materi yang akan dibahas. Pada saat latihan diadakan penentuan kelompok pro atau kontra, dilanjutkan dengan diskusi singkat mengenai alur penyampaian dari setiap kelompok. Kemudian penampilan dari setiap kelompok yang dipandu oleh pelatih, atau senior dari Al-Kindy.

\footnotetext{
${ }^{41}$ Laksmiwati, hlm.5.

${ }^{42}$ Laksmiwati, hlm.6-7.

${ }^{43}$ Rahmaini, hlm.231.
} 


\section{Penutup}

Sesuai dengan hasil penelitian tersebut dapat diambil kesimpulan bahwa adanya penerapan self regulated learning dan self efficacy pada mahasiswa Al-Kindy Pendidikan Bahasa Arab UIN Maulana Malik Ibrahim Malang dalam bidang debat bahasa Arab. Dengan adanya strategi tersebut membantu mahasiswa dalam mengembangkan potensi diri secara mandiri dan lebih maksimal.

Penerapannya strategi untuk belajar debat bahasa Arab efektif dengan bantuan media ICT berupa video, rekaman suara peserta lomba debat terdahulu. Selain itu juga belajar istilah yang biasa dipakai untuk debat dari teman sejawat. Secara keseluruhan strategi self regulated learning dan self efficacy dapat dikategorikan menjadi salah satu faktor kesuksesan dalam belajar debat bahasa Arab pada mahasiswa Al-Kindy Pendidikan Bahasa Arab UIN Maulana Malik Ibrahim Malang.

\section{Bibliografi}

Abd. Mukhid, 'Strategi Self-Regulated Learning (Perspektif Teoritik)', Tadris, 3 Nomor 3 (2008)

Abd.Mukhid, 'Self Efficacy (Perspektif Teori Kognitif Sosial Dan Implikasinya Terhadap Pendidikan)', Tadris, 4 Nomor 1 (2009)

Aminah dkk, 'Pengembangan Metode Pembelajaran Keterampilan Berbicara Bahasa Arab Dengan Kooperatif Berbasis Teori Kecerdasan Majemuk Pada Siswa Kelas VII Madrasah Tsanawiyah', Journal Of Arabic Learning and Teaching, 7 (2018)

Amrullah Sidkin, 'Pengaruh Self Efficacy Dan Self Regulated Learning Terhadap Prokrastinasi Akademik Pada Mahasiswa' (Universitas Islam Negeri Syarif Hidayatullah, 2016)

Bulkisah, 'Pembelajaran Bahasa Arab Pada Pengguruan Tinggi Agama Islam Di Indonesia', Jurnal Ilmiah DID AKTIKA, 12 (2012)

Devita Mawarni, 'Penerapan Pembelajaran Maharah Kalam Dengan Metode Langsung; Studi Kasus Di SMA IT Abu Bakar Yogyakarta' (Universitas Islam Negeri Sunan Kalijaga Yogyakarta, 2016)

Efendi, Rohmad, 'Self Efficacy: Studi Indigenous Pada Guru Bersuku Jawa', Journal of Social and Industrial Psichology, 2 (2013)

Hendri, Muspika, 'Pembelajaran Keterampilan Berbicara Bahasa Arab Melalui Pendekatan Komunikatif', Jumal Kependidikan Islam, 3 (2017)

Kuswono, 'Konsep Dasar Pembelajaran MAharah Al-Kalam', An-Nuba, 4 (2017) 
Laksmiwati, Bekti D. R. dan Hermien, 'Hubungan Antara Self Efficacy Dan Self Regulated Learning Dengan Prestasi Akademik Matematika Siswa SMAN 2 Bangkalan', Character, 03 (2014)

Latipah, Eva, 'Pengaruh Strategi Experiential Learning Terhadap Self Regulated Learning Mahasiswa', Humanitas, 14 No.1 (2017)

M. Irfan dan Veronika Suprapti, 'Hubungan Self-Efficacy Dengan Penyesuaian Diri Terhadap Perguruan Tinggi Pada Mahasiswa Baru Fakultas Psikologi Universitas Airlangga', Jurnal Psikologi Pendidikan Dan Perkembangan, 3 (2013)

Maisaroh, 'Pengaruh Self Efficacy Dan Self Regulated Learning Terhadap Prestasi Belajar Pada Mahasiswa Fakultas Ekonomi Universitas Negeri Jakarta', JP Journal \& Proceeding, 5 (2015)

Paul R. Pintrich, The Role Of Goal Orientation In Self-Regulated Learning Handbook of Self-Regulation (San Diego: Academic Press, 2000)

Rahmaini, 'Strategi Pembelajaran Maharah Kalam Bagi Non Arab', Jurnal Ibya'ul Lughoh, 2 (2015)

Rizqiyah, Ni'matur, 'Pengaruh Strategi Regulasi Diri Dalam Belajar Dan Dukungan Sosial Orang Tua Terhadap Prestasi Belajar Siswa-Siswi SMP Hasanuddin Sepanjang Gondanglegi' (UIN Maulana Malik Ibrahim Malang, 2016)

Saraswati, Putri, 'Strategi Self Regulated Learning Dan Prokrastinasi Akademik Tertadap Prestasi Akademik', Jurnal Intuisi, 9 (3) (2017)

Sidkin, Amarullah, 'Pengaruh Self Efficacy Dan Self Regulated Learning Terhadap Prokrastinasi Akademik Pada Mahasiswa' (Universitas Islam Negeri Syarif Hidayatullah, 2016)

Siti Suminarti dan Siti Fatimah, 'Self Regulated Learning (SRL) Dalam Meningkatkan Prestasi Akademik Pada Mahasiswa', Jurnal Ilmiah Psikologi Terapan, 01 No. 1 (2013)

Sunhaji, 'Konsep Pendidikan Orang Dewasa', Jurnal Kependidikan, 1 (2013)

Syamaun, Nurmasyithah, 'Pembelajaran Maharah AL-Kalam Untuk Meningkatkan Keterampilan Berbicara Mahasiswa Program Studi Pendidikan Bahasa Arab Fakultas Tarbiyah Dan Keguruan UIN Ar-Raniry Banda Aceh', Jurnal Lisanuna, 4 (2015)

Tahir, H. Abd. Wahid, 'Pengembangan Manajemen Sumber Daya Manusia Terhadap Peningkatan Peningkatan Mutu Pendidikan', Jurnal Inspirasi Pendidikan, 1 (2017)

Yusri, Yusnimar, 'Strategi Pembelajaran Andragogi', Al-Fikra, 12 No. 1 (2013) 
28 | Arabiyatuna : Jurnal Bahasa Arab, Vol. 3, No. 1, 2019 